\title{
Analysis on Construction of Natural Rubber Multinational Industry Chain of Guangdong Guangken Rubber Group
}

\author{
Guan Huang $^{1, a}$ and Hongyu $\mathrm{Wu}^{2, \mathrm{~b}}$ \\ ${ }^{1}$ Guangdong Agricultural Industrial and Business Polytechnic, Guangdong, China \\ ${ }^{2}$ Guangdong Agricultural Industrial and Business Polytechnic, Guangdong, China \\ aghuang@gdaib.edu.cn, bhywu@gdaib.edu.cn
}

Keywords: Guangken Rubber Group, "Going out" Strategies, international production eclectic theory, whole industry chain model, multinational industrial chain

\begin{abstract}
Guangken Rubber Group established the first overseas processing plant in 2005. After ten-years of development, the company has formed a complete multinational industrial chain of natural rubber production both at home and abroad. This paper analyzes the rationality and necessity of the global layout of the industrial chain through the historical review of the formation of the multinational industrial chain of Guangken Rubber Group Company, and puts forward the proposal of further integration of the multinational industrial chain under the background of our country' s “one belt, one road” construction.
\end{abstract}

\section{Introduction}

\subsection{Guangken Rubber Group Profile}

Guangken Rubber Group is a subsidiary of Guangdong State Farms specializing in natural rubber industry. The Group was incorporated on August 21, 2002 , and after years of development, the Group developed into large multinational natural rubber industry group with total assets of nearly 64 billion yuan and natural rubber processing capacity of 610,000 tons. The group now owns more than 30 subsidiaries at home and abroad, owns and controls land area of 115 million mu, completes about 88 million mu of rubber plantations. In China, the group owns 32 rubber farms, three branches, two scientific research institutions and eight subsidiaries with the rubber processing capacity of 200,000 tons and rubber planting area of $650,000 \mathrm{mu}$; and in the foreign countries, wholly or controlling holds 20 subsidiaries, owns or controls the land area used for rubber plantations or agricultural development of about 500,000 mu with rubber processing capacity of 410,000 tons and sales revenue of 7.366 billion RMB. Now "Guangken Rubber" has become internationally renowned brand. "Going out" strategy helps the enterprise break through the bottleneck of development. An integrated transnational industrial chain was built at home and abroad, which not only provides abundant reserves of raw materials for Chinese rubber manufacturing industry, and provides a platform for China to cooperate and exchange in the international rubber market, but also provided an opportunity for China as a big rubber consuming country to participate in the international rubber pricing market. "Going out" strategy helps the group to achieved remarkable results.

\subsection{Back ground of "going out"}

The "going out" strategy means that the domestic enterprises in China actively use overseas resources and exploit overseas markets through foreign investment and transnational business, for the purpose of optimizing the enterprise's industrial structure, competitiveness and achieving other strategic objectives. "Going out" began to breed as a national policy from the Deng Xiaoping era, presided over and perfected by President Jiang Zemin, and promoted further to the practical level by President Hu Jintao. After three generations of central collective leadership's continue improvement, 
"going out" strategy has formed a complete theoretical system with Chinese characteristics. Xi Jinping, leader of the new generation of central collective leadership, based on experience and theory of "going out", further proposed a series of specific foreign economic strategy cooperative initiatives such as the construction of "Silk Road Economic Zone" and "21st Century Maritime Silk Road".

Rubber, as an important strategic resource, is the important object supported by "going out" policies. According to the "National Economic and Social and Economic Development Tenth Five-Year Plan", the Ministry of Agriculture put forward the "South Rubber North Beans" industrial development plan, vigorously support the development of natural rubber industry. The plan points out that Guangdong State Farms should play their advantages, and vigorously develop the natural rubber industry; at the same time actively creates the conditions to develop rubber industry in Southeast Asian countries which have nature advantage for rubber planting, and ships back the natural rubber to meet domestic demand. Guangdong Province in the "Pearl River Delta Development Plan" clearly calls for strengthening cooperation with ASEAN, with particular emphasis on resource cooperation. Guangken Rubber Group is one of the 50 important enterprises that are supported by the Guangdong Provincial Party Committee and the provincial government in implementation of the "going out" development strategy. The Guangdong Province provides a special "going out" funds each year to support oversea rubber industry projects of the Group to buy and lease land, build factories, train technical staff and so on.

\subsection{Necessity of "going out"}

Natural rubber industry "going out" is an important choice to ensure the security of strategic material supply in China. China is the world's largest natural rubber consumer and importing countries. There has long been a gap in natural rubber supply, and 2/3 of the rubber demand has to be met by importation. The rubber enterprises in China are limited by geographical location, and there is a natural bottleneck in the production of raw materials. Take Guangken Group as an example, Guangdong's climate is affected by typhoon and chilling injury, and the land is mostly hilly and mountainous. It is not suitable for large-scale cultivation of rubber. The growth rate of natural rubber in the domestic plantation is slow and can not satisfy national strategy and enterprise development needs. Because of its geographical position, Southeast Asia has plenty heat and rain. It is the world's largest tropical economic crops production base, and has always been the most important partner of natural rubber business of China.

According to "The vision and action plan of promoting the construction of the Silk Road economic zone and the 21st century Maritime Silk Road " of Boao Forum on March 28, 2015, Southeast Asia is in the center area of "one belt one road". Rubber is an important economic crop of many countries in Southeast Asia. Cooperation of rubber industry can help to set up a platform for cooperation between China and ASEAN countries. It can be seen that "one belt one road" provides a superior policy background and a good opportunity for rubber industry's development aboard. Guangken Rubber Group owns rich experience in the rubber production and cultivation, and has a professional rubber planting and management team. "Going out" strategy combines the technological advantages of the Group with the geographical advantages of overseas countries. It is the inevitable choice of Guangken Rubber Group to seize the historical opportunity to develop and expand their own business, improve rubber production, solve the demand gap and improve international influence.

\section{Analysis of the Stages of Constructing Transnational Industrial Chain by Guangken Rubber Group}

\subsection{Starting stage}

This stage covers the period from 2005 to 2008. It is the stage to explore the experience of expanding the industrial chain aboard. Natural rubber enterprises "going out" strategy was taken 
into implementation by establishment of overseas production base at this stage. In 2005, the China State Farms System held a seminar to discuss implementation of "going out" strategy. Guangken Rubber Group was formed under such background as a carrier for implementing the "going out" strategy. The Group makes full use of Guangdong's good business service platform, and relies on 60 years of rubber planting and management experience, vigorously carries out foreign cooperation. The Group has become the forerunner in the area of natural rubber "going out ".

Important companies set up at this stage include: (1) Guangken Rubber Tailand (Satun) Ltd., which was set up in April 2005. The company covers an area of $216 \mathrm{Mu}$, mainly produces STR5L, STR20, CPR20, RSS3 \# and other rubber products, with the annual production capacity of 6 million tons; (2) Guangken Rubber Tailand (Trang) Ltd., which was set up in August 2006. The company covers an area of $221 \mathrm{Mu}$, mainly produces concentrated latex, skim rubber, compounded rubber and other rubber products, with the total production capacity of 6 million tons; (3) Guangken Rubber (Sarawak) Ltd., which was set up in November 2006. The company mainly focuses on plantation leasing management and rubber planting business. In 2007, Guangken Rubber(Sarawak) Ltd. cooperated with Malaysian partners to invest 17 million US dollar to build rubber processing project of Guangken Rubber (Sarawak) Industrial Ltd. with annual standard rubber production capacity of 40,000 tons. (4) Guangken Rubber (Borneon) Ltd., which was set up in September 2008. The total investment of the project is 71.441 million US dollars. The rubber planting area has reached 9081 hectares, and 2,000 hectares has reached tapping period in 2016.

Guangken Rubber Group implemented the strategy of "first major rubber producing countries, later the secondary rubber producing countries" , and selected Thailand and Malaysia as the first step in the development abroad . Not only because the two countries are the main origin of rubber and have geographical advantages, but also because the two countries have stable political situation and mature economic system that are essential to the development of enterprise. At this stage, the Guangken Rubber Group explored a variety of business cooperation model. As a search for implementing "going out" strategy, the Group firstly built processing plants in a more flexible way of mergers, acquisitions and equity cooperation. In the process of cooperation with foreign partners, the Group continually summed up the experience of cooperation with foreign partners, studied foreign production and management conditions, and gradually expanded the industrial chain from processing to plantation. As the former general manager of the company Lai Siren said, the processing plant could only complete the primary processing of natural rubber, and can not control the resources. "Only large size rubber plantation can ensure the stability of the domestic supply of natural rubber"[1]. The valuable experience accumulated at this stage lay a solid foundation for Guangken Rubber Group's building of transnational industrial chain .

\subsection{Forming stage}

This stage covered the period from 2008 to 2012. The international industrial chain began to take shape, and more emphasis had been put on "going out" work. Guangken Rubber Group put great effort in promoting the development of oversea natural rubber plantation and industrial construction, and ensure the stable supply of domestic natural rubber. Through the effort, the company's rubber production and quality were improved, and the rubber plantations and processing plants had certain scale. At the same time, the Group perfected the cross-border industrial chain layout by setting up seedling cultivation bases in upstream and laying the sales channels in downstream of the natural rubber industry chain. It can be said that the Guangken Rubber Group has become a leader of natural rubber "going out" business.

Important companies set up at this stage include: (1) Thai Guangken Rubber (Mekong) Ltd., which began to construct at the end of 2010. The company mainly produces all kinds of standard rubber and composite rubber in Thailand, and the design annual production capacity is 50,000 tons. The company went into operation in 2012. (2) Indonesian Guangken Rubber (Pontiana) Ltd., which was set up in December 2010. Pontianak factory mainly produces all kinds rubber products of Indonesia standard, such as standard rubber and composite rubber, and the annual production capacity was 40,000 tons. (3) Thai Guangken Rubber (East Thai) Ltd., which was incorporated in 
November 2011. The company covers an area of $276 \mathrm{mu}$, which is wholly owned by Guangken Rubber Group. It mainly produces No.3 smoked sheet rubber, Thai standard rubber, compound rubber and other rubber products, the total production capacity is 40,000 tons. (4) Thai Guangken Rubber (South Thai) Ltd., which began to build in 2012.The company covers an area of 24.86 hectares, with a registered capital of 300 million baht and annual designed production capacity of 40,000 tons. (5)Malaysian Guangken Rubber (Sarawak) Planting Ltd., which was incorporated in March 2012. The total investment is 84.2 million US dollars, and the plan is to build 10,000 hectares of natural rubber planting base. (6) Guangken Rubber (Cambodia) Ltd., which began to construct in 2012. The company planed to build 42,000 hectares of rubber plantation. (7) Malaysian Sanken Rubber (Sarawak) Seed Co., Ltd., which was incorporated in March 2012. The company's major business is to cultivate rubber seedling, palm seedling and other tropical fruit seedlings. At the same time, it is also built as a the tropical economic crop seed center and modern agriculture demonstration park for modern agriculture training, demonstration, and visit. It plans to produce 10 million rubber seedlings , 5 million palm seedlings, and 2 million other fruit seedlings per year. (8) Guangken Rubber (Singapore) Ltd., which was established in 2011. The company is mainly engaged in business of natural rubber trading, raw materials procurement, market information collection, and overseas marketing of natural rubber products. To 2014, the natural rubber trade volume reached 171,302 tons, the sales income 2104.94 million yuan, and net profit 90,000 yuan.[2]

Combing the development of this stage, it is clear that the focus of investment was gradually shifting from rubber processing factories to planting industry, which is consistent with national interests and strategic needs. The investment of planting industry is a long term business and normally needs large capital support. It is the rational choice of Guangken Rubber Group to enter the planting industry carefully after accumulation of a wealth of overseas investment and construction experience. In addition, the investment area is also greatly expanded. In addition to Thailand and Malaysia, Indonesia, Cambodia and Singapore are also included in the target investment countries. Guangken Rubber Group not only increases the production of overseas natural rubber significantly, but also creates internationally renowned brand "Guangken Rubber”, promotes the cooperation and communication with the rubber production counties, and creates a good international corporate image. At this stage, Guangken Rubber Group completed domestic and foreign industry docking and transnational industrial chain layout, and enhance the core competitiveness of China's natural rubber production companies. After 10 years' steady development of "going out", Guangken Rubber Group has formed the whole industry chain development model which includes domestic research and personnel training base, Malaysia-Cambodia seedling and planting center, Thailand-Malaysia-Indonesia rubber processing center and the Singapore trade platform.

\subsection{Integrating stage}

This stage covers the period of 2013 to now, and it is an strategic integration stage of industrial chain. Southeast Asia is the main producing areas of natural rubber, and the most important partners of Guangken Rubber Group in implementing of the "going out" strategy. In 2013, China proposed the policy ideas of "Building the Maritime Silk Road in Twenty-first Century Together" to further promote China - ASEAN economic integration, which created a new historical opportunity for the rubber business "going out". In 2014 Qingdao Rubber Industry Expo, the representatives of of different rubber producing countries reached agreement that "Rubber Trading Should Take the First Step in the Silk Road cooperation", which provides a good platform for international cooperation of rubber industry. Under this background, Guangken Rubber Group on the one hand further expanded the scale of enterprises, on the other hand integrated the existing resources and put more emphasis on constructing the planting center in Cambodia, processing center in Thailand and trading center in Singapore.

The most important companies incorporated at this stage include (1) Cambodia Chunfeng Rubber Co., Ltd., which was established in 2013. The company's total investment is 70.5 million 
US dollars, covering 12,000 hectares of land, and mainly focuses on rubber planting. (2) Guangken (Cambodia) Agricultural Science and Technology Co., Ltd., which was established in November 2014. The company's total investment is 6.35 million US dollars. It is proposed to build an advanced seed breeding center to ensure the seedling demand of the planting in Cambodia. (3)Thai Hua Rubber Public Limited, the world's third largest manufacturer and exporter of natural rubber products, was sucessfully acquired by Guangken Rubber Group in August 2016, . Thai Hua company was established in 1978, whose headquartered is located in Bangkok. The company's registered capital is 2.3 billion baht, and has more than 30 subordinate enterprises. The annual processing capacity is 920,000 tons, and owns more than 30 million mu land. After the successful acquisition of Thai Hua Company, the Group now owns the world's largest natural rubber industry chain, with an annual rubber production capacity of 1.5 million tons and planting area of $200 \mathrm{mu}$.

From the perspective of international industrial chain integration, the natural rubber industry chain mainly includes the following parts: research and development of technology of natural rubber planting and processing, seed cultivation, rubber planting, rubber tapping, rubber processing, logistics, marketing and other sectors; and these sectors should be arrange and laid out across different countries in a logical way. Guangken Rubber Group extended the industrial chain abroad to the upstream, and set the planting center in Cambodia, which has superior natural conditions for rubber planting, rich land resources, loose political environment and low labor costs; set the processing center in Thailand, where the technology is mature, the economic system is relatively perfect, and the political system is stable; and set the trading center in Singapore, where the financial activities are prosperous, trading is active and shipping market is matured. The future development will further strengthen the various links in the industrial chain, integrate the resources, and enhance competitiveness of the natural rubber industry chain.

\section{Analysis on Competitiveness of Guangken Rubber Group 's Multinational Industry Chain Model}

Guangken Rubber Group implementing the "going out" strategy is to better allocate the corporate resources, ensure the supply of raw materials, construct the oversea production base, and develop the international market. The aim of extending the industrial chain to foreign countries is to achieve rational division of the production sector in a global background, and better combine the advantages of the Group’s management experience and natural resources abroad.

According to the eclectic paradigm of international production proposed by Professor Dunning of University of Reading UK, when engaging in foreign direct investment, companies must have the advantages of Ownership, Location and Internalization, which are the so-called OLI advantages. Ownership advantage refers to the advantages that are specific to the company itself, including technological superiority, monopoly advantage, organizational management advantages and financial and monetary advantages; Location advantage refers to the alternative countries or regions may have attractions for their locations or investment environment, such as labor costs, market potential, trade barriers, government policies, climate and natural resources; Internalization advantage refers to the advantage that companies can gain by organizing and internalizing cross-border factors of production and products to increase its core competitiveness, including controlling the cost and resources.[3]

Guangken Rubber Group's whole industry chain model is to integrate different sectors of production into the enterprise and achieve a complete production chain. In building the cross-border industrial chain, Guangken Rubber Group have OLI advantages in foreign direct investment: 


\begin{tabular}{|l|l|}
\hline Ownership (O) & $\begin{array}{l}\text { (1) } 65 \text { years experience of rubber planting } \\
\text { (2) Rich human resources } \\
\text { (3) Matured rubber planting, tapping and processing } \\
\text { technology } \\
\text { (4) Perfect management system } \\
\text { (5) Strong capital operation }\end{array}$ \\
\hline Internalization (I) & (1) Ensure the supply of raw materials \\
& (2) Control the production standards \\
(3) Sustain the market and costumer relations \\
(4) Attend the international rubber market pricing
\end{tabular}

There are five modes of construction of the industrial chain, including construction by perfect competition of the market, construction by internalization and integration, construction based on the leadership of core enterprise, construction based on social factors and relationship, construction based on the depth division of labor.[4] Guangken Rubber Group use the integration and internalization construction model, building the cross-border industrial chain is actually a process of internalizing and integrating the rubber production sectors globally. The competitiveness of the Group's cross-border industrial chain can be listed as following:

(1) Technology development: Guangken Rubber Group has strong technology support and puts great emphasis on science and technology development. It takes innovation as the driving force of the enterprise and keeps increasing investment in scientific research, encouraging the innovation, improving core competitiveness of products and promoting sustainable and stable development of enterprises. The Group set up a technology innovation center in 2007, introducing highly skilled, high-level scientific and technological personnel. The center aims to exploit the key technology, develop high-end products, and strengthen quality inspection and testing. It plays important roles in promoting production and research cooperation, technological innovation and commercializing the research findings. The scientific research projects of the center won the second prize of "National Science and Technology Progress Award ".

(2) Seedling cultivation: Guangken Group formed a tropical crop science research institute. The institute uses the advanced rubber bud grafting technology and owns the largest rubber seedling breeding center, which provides important support for the development of rubber industry. In research and development of seedling cultivation and planting technology, Guangken Rubber Group relies on its subsidiary of Guangken tropical research institute, and at the same time cooperates with the Rubber Research Institute of Chinese Academy of Tropical Agricultural Sciences. The research team constitutes of experts on genetic breeding, cultivation, soil nutrient analysis and so on. The experts make comprehensive research on rubber variety breeding, tissue cultivate technology, rubber tree care, rubber pest control, planting methods comparison, new tapping technology and other aspects. The technology of rubber production forecast in seedling period, rubber pollen, anther cultivation technology, and rubber stable triploid cultivation methods have reached the world leading level.

(3) Planting and processing: Guangken Rubber Group's advantages are mainly in its strong technology and matured management system. In order to promote the industrialization operation of the rubber business, the company has adjusted the location of rubber processing plants, and the centralized the production of rubber processing in Maoming, Yangjiang and Zhanjiang Cities. In this way, the company can focuses on building modern rubber processing plants and applies 
advanced processing technology and skills. Guangdong State Farms' long history and advanced technology has provided good foundation for the operation of the project. And now the main products of the company is in the leading place of the world and the company owns rigorous organizational system and sound management system.

(4) Trading: Guangken Rubber Group has established two international trading centers and six trading offices in Guangzhou, Qingdao, Shanghai, Tianjin, Xiamen and other rubber distribution centers. Based on the trading companies in Thailand and Singapore, and centered on the headquarter in Guangzhou, Guangken Rubber Group has set up global marketing network system covering domestic, foreign, futures hedging and electronic trading markets. The Group owns brand standard system and creates the internationally renowned brand "Guangken rubber". The Group wins the honor of "integrity rubber industry service providers," and establish integrity management image.

It can be seen that the weakest link in the rubber industry chain of Guangken Rubber Group is the lack of natural rubber planting environment. Southeast Asian countries are rich in land resources that are suitable for planting rubber and in urgent need of develop. "Going out" help Guangken Rubber Group to to make good use of the comparative advantages of Southeast Asian countries in the natural resources, improve the competitiveness of the entire industry chain, give the corporate a louder voice in the international market, and ensure the resources supply.

\section{Perfection of the industrial chain under the "going out" background}

4.1 Actively expand the depth and breadth of the industrial chain. At present, the industrial chain of Guangken Rubber Group mainly includes five sectors: technology development - seedling cultivation - rubber planting - processing - trading. Although the chain is relatively complete, but it mainly focuses on the primary production stage. The chain is short and the additional value of the product is low, which make the chain vulnerable to changes and impacts of large economic environment. To broaden the industrial chain, the Group must improve the scientific research and technology in the downstream of the chain. The core competitiveness of enterprises should be reflected in the improvement of technical level. Technology can make all aspects of the industry chain upgrade. Firstly, Guangken Rubber Group should not only further improve the technical level of raw rubber and primary processing products, but also actively develop deep processing products, including the tire production in the downstream of the chain, to improve the value of rubber products. Secondly, Guangken Rubber Group need to improve the brand value and expand the brand's influence. In addition to promoting corporate image and models of corporate employees, the Group should build the leading brand by mining the connotation of the brand, improving product quality, and actively exploring the market. Thirdly, capital operation can be added to the industry chain and create "financial + manufacturing" model of the industrial chain. [5] Adding the financial sector to the industry chain can help to make use of the pricing adjustment and expectation function of financial market, guide the enterprise to make investment, strengthen corporate financing capacity, and scatter business risks. Guangken Rubber Group has a wealth of equity investment and capital operation experience. It can try to enter the futures market and better play the role of financial market in the development of enterprise. 


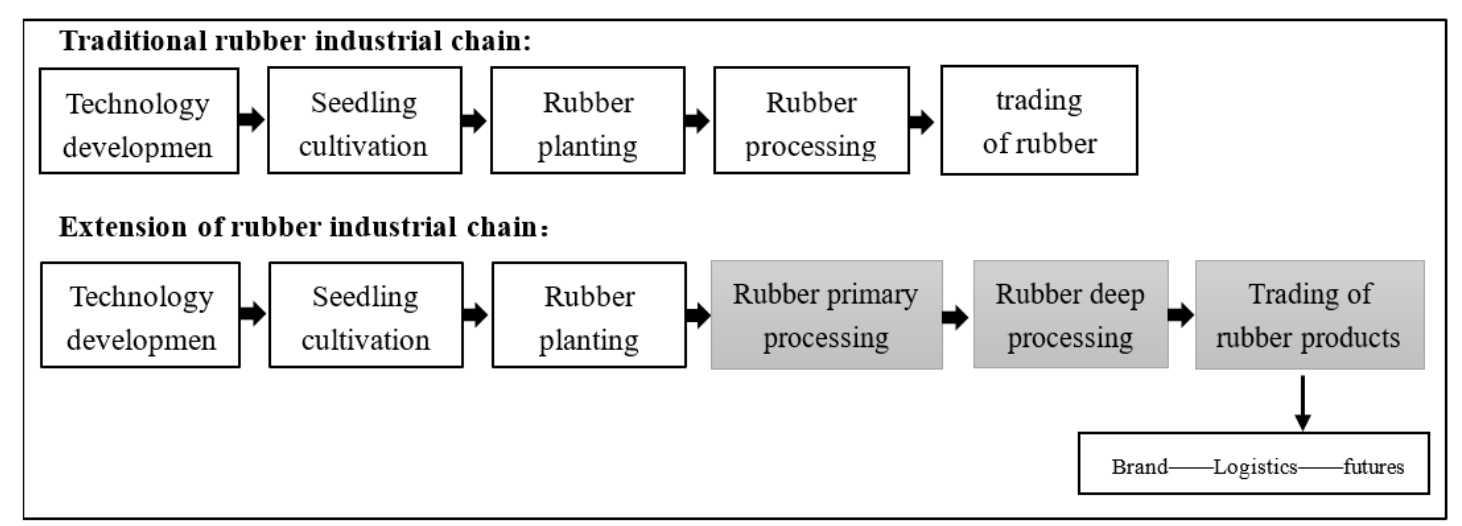

4.2 Strengthen the links in all aspects of the industry chain in domestic and international markets. The main focus of Guangken Rubber Group is now on the overseas production base. The oversea production and sales accounted for more than $90 \%$ of the company. However, the group should be clear that the root and the core competitiveness of the enterprise is still in the China. The advantages of the domestic base include technology, capital operation, talent, advanced production techniques and management system, which also constitutes the base for implementing "going out" strategy. Guangken Group's owns independent rubber processing technology innovation center and production technology department in the Group headquarters. Research team constitutes of 200 researcher with bachelor degree or above and senior titles. The Group has 2,072 professional personnel in every sector of rubber business, including 108 senior titles, 452 intermediate titles, and 1,512 junior titles. The strong research and technical team provides support to improve the production process, refine product formulations and research and development of new products. Guangken Rubber Group should take domestic production base as the engine for creation and dynamic, improve the level of theoretical and policy research, construct talent incubation base, strengthen the control of the industrial chain, effectively dock and embed the advantages of various sectors domestic and abroad, and achieve a comprehensive integration of the industrial chain layout internationally.[6]At present, the company has already formed a relatively complete industrial chain both domestically and abroad. The Group should give full play to the advantages of domestic technology and talents as the core competitiveness of enterprises, and make use of resources and geographical advantages of foreign production base, convey the advantages of domestic industrial chain to foreign industrial chain, organically combination the chains at home and abroad, and form dual radiation global industry chain model.

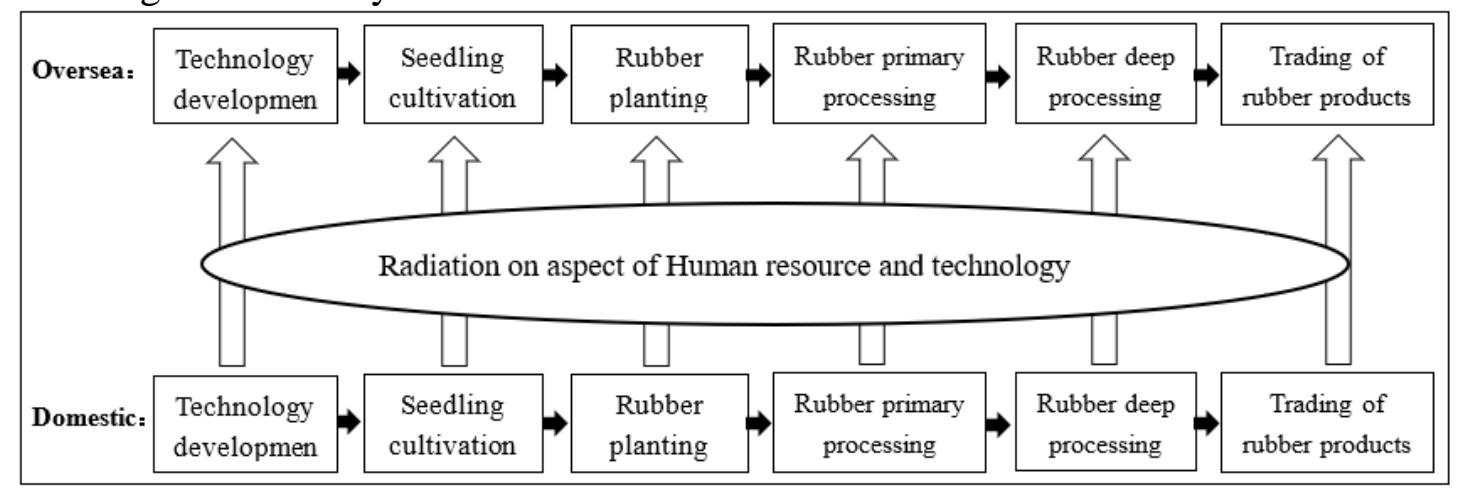

4.3 Strengthen the management and planning of plantations. In integration of the industrial chain, an important issue to be considered is the layout of the industrial chain and the focus of the enterprise investment. Planting, processing and sale are three most important sectors in natural rubber industry chain. Plantation provides the strongest control for rubber resources supply, but it needs to cooperate with the local government and people most closely, and is greatly influenced by the local political and economic stability. Correspondingly, if the Group choose to obtain rubber resources on the market through capital operation, the risks will be relatively low and the efficiency will be relatively high, but the control of resource supply will be reduced. Guangken Rubber Group 
still choose to set its first mission as to ensure the stable supply of domestic rubber resources. Therefore, the focus of the Group is on the construction of overseas plantations in the integration of the industry chain. However, companies alone can not afford such a huge investment risk. Therefore, the company should actively seek the government's policy support, including tax incentives, overseas investment insurance policy, agricultural fund subsidy policy, in order to seek a more stable long-term development of enterprises.

\section{References}

[1] Zou Xilan, Chen Wenjuan , Guangdong State Farms build overseas rubber bases to seize the right to determine the international rubber market pricing, http: //www.sina.com.cn, May 25, 2009 00:57, China Economic Weekly.

[2] Huang Guan, Wu Hongyu, Natural rubber cultivation and practice of "going out" strategy in Guangdong State Farms, China Tropical Agriculture[J], 2016(3):18-21

[3] J.H.Dunning, The Determinants of International Production, Oxford Economic Papers[J]., 1973,(03).

[4] Wu Yanyan, The research of industrial chain integration and upgrading of[D]. Tianjin University Doctoral Thesis, 2009: 41-45

[5] Zhang Hong, Xu Nengrui, Constructing the whole industry chain of natural rubber in China -Taking Hainan Rubber Group as an example, China Tropical Agriculture[J] , 2012 (1): 11-14

[6] Fu Guohua, Zhang Hui, Zhang Desheng, The "go global" strategy of China's natural rubber and the construction of spatial industry chain model, Study on Agriculture Modernization[J], 2011(33-6):713-716 